\title{
A systematic review of the direct and indirect effects of herbivory on plant reproduction mediated by pollination
}

\author{
Stephanie M Haas ${ }^{\text {Corresp., } 1}$, Christopher J Lortie ${ }^{1,2}$ \\ 1 Department of Biology, York University, Toronto, ON, Canada \\ 2 The National Center for Ecological Analysis and Synthesis, University of California, Santa Barbara, Santa Barbara, California, United States \\ Corresponding Author: Stephanie M Haas \\ Email address: shaas014@yorku.ca
}

Background. Plant reproduction is influenced by the net outcome of plant-herbivore and plant-pollinator interactions. While both herbivore impacts and pollinator impacts on plant reproduction have been widely studied, few studies examine them in concert.

Methodology. Here, we review the contemporary literature that examines the net outcomes of herbivory and pollination on plant reproduction and the impacts of herbivores on pollination through damage to shared host plants using systematic review tools. The direct or indirect effects of herbivores on floral tissue and reported mechanisms were compiled including the taxonomic breadth of herbivores, plants, and pollinators.

Results. A total of 4304 studies were examined producing 61 relevant studies for synthesis that reported both pollinator and herbivore measures. A total of $53 \%$ of studies examined the impact of direct damage to floral tissue through partial florivory while $35 \%$ of studies also examined the impact of vegetative damage on pollination through folivory, root herbivory, and stem damage. Only 4 studies examined the effects of both direct and indirect damage to pollination outcomes within the same study.

Conclusions. It is not unreasonable to assume that plants often sustain simultaneous forms of damage to different tissues and that the net effects can be assessed through differences in reproductive output. Further research that controls for other relative drivers of reproductive output but examines more than one pathway of damage simultaneously will inform our understanding of the mechanistic relevance of herbivore impacts on pollination and also highlight interactions between herbivores and pollinators through plants. It is clear that herbivory can impact plant fitness through pollination; however, the relative importance of direct and indirect damage to floral tissue on plant reproduction is still largely unknown. 
1 A systematic review of the direct and indirect effects

2 of herbivory on plant reproduction mediated by

3 pollination

4

5

6

7

8

Stephanie M Haas ${ }^{1}$, Christopher Lortie ${ }^{1,2}$

${ }^{1}$ Department of Biology, York University, Toronto, Ontario, Canada

2 The National Center for Ecological Analysis and Synthesis, University of California, Santa Barbara, Santa Barbara, California, United States

Corresponding Author:

Stephanie Haas ${ }^{1}$

4700 Keele St, Toronto, Ontario, M3J 1P3, Canada

Email address: shaas014@yorku.ca

\section{Abstract}

Background. Plant reproduction is influenced by the net outcome of plant-herbivore and plantpollinator interactions. While both herbivore impacts and pollinator impacts on plant reproduction have been widely studied, few studies examine them in concert.

Methodology. Here, we review the contemporary literature that examines the net outcomes of herbivory and pollination on plant reproduction and the impacts of herbivores on pollination through damage to shared host plants using systematic review tools. The direct or indirect effects of herbivores on floral tissue and reported mechanisms were compiled including the taxonomic breadth of herbivores, plants, and pollinators.

Results. A total of 4304 studies were examined producing 61 relevant studies for synthesis that reported both pollinator and herbivore measures. A total of $53 \%$ of studies examined the impact of direct damage to floral tissue through partial florivory while $35 \%$ of studies also examined the impact of vegetative damage on pollination through folivory, root herbivory, and stem damage. Only 4 studies examined the effects of both direct and indirect damage to pollination outcomes within the same study.

Conclusions. It is not unreasonable to assume that plants often sustain simultaneous forms of damage to different tissues and that the net effects can be assessed through differences in reproductive output. Further research that controls for other relative drivers of reproductive output but examines more than one pathway of damage simultaneously will inform our understanding of the mechanistic relevance of herbivore impacts on pollination and also highlight interactions between herbivores and pollinators through plants. It is clear that herbivory can impact plant fitness through pollination; however, the relative importance of direct and indirect damage to floral tissue on plant reproduction is still largely unknown. 
41

42

43

44

45

46

47

48

49

50

51

52

53

54

55

56

57

58

59

60

61

62

63

64

65

66

67

68

69

70

71

72

73

74

75

76

77

78

79

80

81

82

83

84

\section{Introduction}

Plant fitness is determined in part by the net outcome of interactions with other species. All species within a community experience multiple direct interactions ranging from negative to positive (García-cervigón et al. 2016, Pilosof et al. 2017). However, the sum of the direct interactions between two species do not represent the net outcome of the relationship since they are non-additive; these direct interactions can in turn interact (Proulx, Promislow \& Phillips, 2005). When each species interacts with at least one third party species, indirect interactions quickly occur (Borrett, Whipple \& Patten, 2010). It is the sum of these direct and indirect interactions that represent the net outcome of the interaction between any two species (Michalet et al., 2015).

For most angiosperms, interactions with herbivores and pollinators impact fitness. Herbivory can be generally classified as having a direct negative effect on plants, while pollinators can be similarly classified as having a direct positive effect. Typically, herbivory and pollination are examined one at a time; however, these effect pathways frequently co-occur and therefore interact and so the net outcome is not necessarily as straightforward as these simple classifications (Strauss, Conner \& Rush, 1996; Vulliamy, Potts \& Willmer, 2006; Tsuji et al., 2016; Chalcoff, Lescano \& Devegili, 2019; Rusman et al., 2019; Scopece, Frachon \& Cozzolino, 2019). In this systematic review (Fig. 1), we have outlined a conceptual framework (Fig. 2) to illustrate the direct and indirect ways in which the negative effects of herbivory can both directly and indirectly effect plant fitness via animal pollinators and pollination. Here, we outline the general ways in which different types of herbivory can impact plant fitness and how this interacts with pollination as outlined in Fig. 2, followed by a synthesis of the contemporary literature on herbivore-pollinator interactions.

Herbivory alone can impact plant reproduction both directly and indirectly, regardless of pollination. Partial florivory (damage to floral tissue) or complete florivory (complete removal of flowers; see Table 1 for a list of definitions) can reduce plant fitness by directly reducing the capacity of a flower to produce seeds. However, herbivores can also remove or damage nonfloral (vegetative) structures such as leaves (folivory), stems (stem damage), and roots (root herbivory). Damage to these structures can cause a plant to either not produce flowers, fruits or seeds, or produce structures of poor quality (i.e. non-viable seeds; Brody, 1997; Mothershead \& Marquis, 2000; Lucas-Barbosa 2016; Rusman et al., 2019). Regardless of any indirect interactions via pollinators herbivores can result in a negative net outcome on plant fitness.

The results of these types of damage influence floral display and therefore pollinator visitation. Removal of flowers not only eliminates a potential source of resources for pollinators, but also decreases the overall size of the floral display. Rather than removing flowers, partial florivory can make flowers directly less attractive to pollinators by reducing symmetry (BottoMahan et al., 2011). Partial florivory can also have indirect effects on floral traits and pollinator attraction similar to consumption of vegetative (non-floral) tissues (discussed below) such as reduction in flower size and nectar production (Krupnick, Weis, and Campbell, 1999; Mothershead \& Marquis, 2000).

Vegetative herbivory such as folivory, root herbivory, and stem damage (Table 1) can indirectly influence floral display (similar to partial florivory). They can cause plants to produce fewer and smaller flowers (Strauss, Conner \& Rush, 1996; Hambäck, 2001; Hladun \& Adler, 2009) as well as change the morphology of flowers (including symmetry or architectural 
85 structure) (Strauss, Conner \& Rush, 1996; Table 1; Mothershead \& Marquis, 2000; Suárez, 86 Gonzáles \& Gianoli, 2009). Phenology, sex ratio, and pollen production can further shift with 87 vegetative herbivory (Strauss, Conner \& Rush, 1996; Mothershead \& Marquis, 2000; Avila88 Sakar, Simmers \& Stephenson, 2003; Arceo-Gómez, Parra-Tabla \& Navarro, 2009). In these ways, both vegetative and floral damage can interact with pollination.

While herbivory is inherently negative and can have negative impacts on pollination, the net outcome of herbivory both on pollination and plant reproduction is not necessarily negative. The net outcome is mediated by plant responses (Santangelo, Thompson \& Johnson, 2019) in terms of resistances, allocation strategies, and defenses (see Hawkes \& Sullivan, 2001). Plants can overproduce in preparation for herbivory or compensate for herbivory received by producing more structures or switching to self-pollination, reducing the overall impact (Garcia \& Eubanks, 2019). Plants can also deter herbivores through defenses including constitutive (e.g. thorns) or inducible (e.g. volatile release) defenses that can be both mechanical or chemical (Chen, 2008). Plants may also reduce herbivory by interacting with other non-herbivore species such as other plants (Ruttan \& Lortie, 2013) and predators (Heil, 2008). By reducing herbivory or mitigating the damage caused by herbivores, plants are able to reduce their impact on pollination and plant reproduction. However, a cost to some defenses include deterring pollinators (LucasBarbosa, Van Loon \& Dicke, 2011).

Numerous mechanistic pathways can integrate the direct and indirect impacts of herbivores on plant reproduction through plant tissue, allocation strategies, and timing that impact plant pollination (Strauss, Conner \& Rush, 1996; Mothershead \& Marquis, 2000; Kelly et al., 2008; Botto-Mahan et al., 2011). In turn, negative impacts to pollinators can amplify the negative effects of herbivores on plant fitness by reducing both potential seed set (e.g. number of flowers available to set seed) (Strauss, Conner \& Rush, 1996; Hambäck, 2001; Rusman et al., 2019) and actual seed set (i.e. flowers are not all pollinated due to decreased pollinator visitation) (Adler, Karban \& Strauss, 2001; Benning \& Moeller, 2019). The nature of how not only each type of herbivory, but also the joint impact of multiple types of herbivory impact pollination and plant reproduction are the basis of Fig. 2 .

In this systematic review, we synthesize the contemporary literature on herbivore-plantpollinator interactions with a specific focus on studies that examined the joint impact of herbivores and pollinators on plant reproduction or the impact of herbivores on pollination using the mechanistic pathways proposed in our conceptual framework (Fig. 2). The frequency of mechanisms tested and the frequency that direct vs indirect floral damage pathways are contrasted is important to both ecology and evolution. This includes examining the diversity of types of damage - both the tissue targeted and the taxa causing the damage. Finally, we examine how each mechanism is tested.

\section{Survey methodology}

A search for papers that examine the impact of herbivores on pollinators or the pollination of plants in October 2019 using Web of Science and the search terms "herbivor* AND pollinat", "floriv", "foliv* AND pollinat", "herbivor" AND flower", and "foliv* AND flower" was conducted by S. Haas (no review protocol was registered). This resulted in 3681 papers (Fig. 1). Papers had to meet the criteria that they directly tested the impact of herbivory on animal-mediated pollination. The indirect effect of herbivores on pollinators or the indirect effect 
129 of herbivores on plants via pollinators must have been reported to be included in this synthesis

130 (e.g. through measuring pollen deposition or comparing open pollination to supplementary hand

131 pollination). After review, 59 papers were included in the final analysis (Fig. 1). Papers that were

132 excluded were reviews and descriptions of the natural history of plants or animals (including

133 diet). Studies were also excluded if they examined the impact of herbivores on plants but not

134 pollination. Studies had to specifically test some effect pathway from herbivores to pollinators,

135 studies that included both herbivores and pollinators but examined their effects on plants

136 independently or examined the effect of some other factor on each group were not included

137 Studies on other types of consumption, such as nectar robbing, gall-forming insects, seed

138 predation, and frugivory (consumption of fruits) were excluded. Plants also had to be animal-

139 pollinated (at least in part). Data extracted included the physical location of all study sites and

140 the taxa examined, as well as the analyses performed (including type of herbivory, response

141 variable, and general direction of effect each variable had on each response) and the general

142 structure of the experimental design. Site biomes were calculated using biomes from Terrestrial

143 Ecoregions of the World, originating from the World Wildlife Fund (Olson et al., 2001; CC BY-

144 NC 3.0) using the software QGIS (QGIS Development Team, 2019).

145

146

Results

147

148

In total, 59 papers met all criteria to be included in the final analysis. These papers

149

150

151

152

153

154

155

156

157

158

159

160

161

162

163

164

165

166

167

168

169

170

171

172 ranged from 1995 to 2019 spanning 18 different countries and 11 (of 14) different biomes (Fig. 3). The majority were done in the United States and the temperate broadleaf \& mixed forests biome. The only biomes not represented were tropical \& subtropical coniferous forests, tropical \& subtropical grasslands, savannas \& shrublands, and tundra. Of the 51 papers in which site information could be taken (that were not greenhouse experiments) all but three studies were located within a single biome. A total of 47 plant taxa, 27 herbivore taxa, and 18 pollinator taxa were studied in these papers (Table S1; Fig. 4). Almost all herbivores (81\%) and pollinators $(78 \%)$ were insects. A total of $90 \%$ of studies $(\mathrm{N}=55)$ examined a single plant species while only $43 \%$ of studies $(\mathrm{N}=26)$ examined a single herbivore and $10 \%$ a single pollinator $(\mathrm{N}=6$; Table $\mathrm{S} 2$ and S3). It was most common to examine the entire community of pollinators ( $72 \%$ of studies; $\mathrm{N}=44)$. Pollination was most frequently measured through direct pollinator visitation $(57 \%$ of studies); however, $25 \%$ used supplemental pollination (Table 1). Herbivory was also most frequently $(67 \%)$ observed directly by animals although $33 \%$ of studies $(N=20)$ applied some form of artificial herbivory, and $22 \%$ artificially reduced herbivory by excluding herbivores or applying pesticides.

The most common type of herbivory examined was florivory (49\%; Fig. 5, Table 1), with every one of these studies examining partial florivory and only one also examining complete florivory. This was followed by folivory (27\%) and grazing (20\%). However, stem damage (8\%) and root herbivory (5\%) were also utilized. For $5 \%$ of studies, herbivory was non-specific (i.e. "open" to all herbivores). Almost all studies (88\%) looked at only one form of herbivory. Of the other $12 \%$ of studies, two or three types of herbivory were examined. Hladun and Adler (2009) examined the interaction between two types of vegetative herbivory-root herbivory and folivory. Buchanan (2015) also compared two types of vegetative herbivory: leaf damage and meristem damage, while Rusman et al. (2019) looked at all three types of vegetative herbivory (folivory, stem damage, and root herbivory). Similarly, Sasal et al. (2017) looked at both general 
173 grazing (in the form of ungulates) and specifically folivory (in the form of insect herbivory).

174 Lucas-Barbosa et al. (2013), Lucas-Barbosa et al. (2016), and Mothershead and Marquis (2000)

175 compared the effects of florivory and folivory representing the only papers that compared

176 vegetative and floral herbivory.

177 Florivory was found to have some negative impact on floral expression, pollination, or

178 seed production in $86 \%$ of papers (Supplemental Table S4). Some positive effect of florivory

179 was found in $24 \%$ of papers and a neutral effect in $48 \%$ of papers. For folivory, $81 \%$ of papers

180 each found some negative effect or neutral effect, while only $31 \%$ found any positive effect.

181 Grazing had $67 \%$ of papers each find some negative or neutral effect, and $33 \%$ found some

182 positive effect. Similar proportions were found in each of the other types of herbivory.

183

184

Only $19 \%$ of papers took a full mechanistic approach to the effects of herbivores on pollinators (Table 2). These studies examined each point of the mechanism in Fig. 2: the effects of herbivory on floral display, pollinators, and plant reproduction. Most frequently $(24 \%)$, papers examined the effect on pollinators and plant reproduction while skipping the mechanistic step of the impact on the flower. Otherwise, there was an approximately equal split between only examining effects on pollinators ( $15 \%$ ), only examining the effect of supplemental pollination on reproduction (12\%), examining the floral attributes and reproduction without the pollinator $(15 \%)$, or the floral attributes and pollinator without reproduction (15\%).

191

192

\section{Discussion}

Herbivory and reproduction in plants are intimately linked through interactions with animals. In this systematic review, we examined the relative frequencies and the extent that these important processes are studied in concert. While the effect of herbivores on plants have long been studied, and it has been well shown that herbivores can directly and indirectly impact plant reproduction, growth, and population dynamics (Hawkes \& Sullivan, 2001; Ohgushi, 2005; Boivin, Doublet \& Candau, 2019; Garcia \& Eubanks, 2019), the small number of studies that were located within this review indicate how infrequently the effects of herbivores on pollination are studied. These studies were also heavily biased towards damage done by insects, temperate biomes, and the effects of a single herbivore species on a single plant species. Furthermore, only a handful of studies compared direct and indirect effects of herbivory on floral traits and pollination. Given that most animal-pollinated plants likely experience damage to multiple tissues as well as pollination (Lucas-Barbosa, 2016), this is an unfortunate gap in the

205

206

207 literature. In addition, those few studies that do examine both herbivory and pollination frequently examine only the net outcome and not the underlying mechanism (i.e. how herbivory impacts floral traits and how floral traits impact pollination). That is, most studies do not fully examine the interaction network outlined in our framework (Fig. 2). Examining the impacts of multiple herbivores as well as multiple types of herbivory is important in determining how plants and pollinators are impacted by real communities of herbivores.

\section{Effects of Florivory on Pollination}

Direct damage to floral tissue is an important factor in determining plant reproductive output. Complete florivory has been shown to have direct impacts on floral abundance. The net outcome of this form of direct damage is dependent on the strategy of the plant (Juenger \& Bergelson, 1997; Wise, Cummins \& De Young, 2008; Garcia \& Eubanks, 2019). In some cases, 
217 plants will over-produce flowers as a defense against florivory creating more flowers than the 218 plant is able to bring to seed (e.g. Huth \& Pellmyr, 1997). Therefore, florivory frequently results 219 in no net loss in reproductive output for the plant. In other cases, plants are able to compensate

220

221

222

223

224

225

226

227

228

229

230

231

232

233

234

235

236

237

238

239

240

241

242

243

244

245

246

247

248

249

250

251

252

253

254

255

256

257

258

259 or overcompensate for herbivory, replacing the flowers lost (sometimes producing more flowers than initially), delaying phenology (Wise, Cummins \& De Young, 2008; Garcia \& Eubanks, 2019), or changing. If the plant is able to completely compensate (reproduce flowers of equal or greater quality and quantity) then the net effect of complete florivory is neutral or even positive. How plants interact with florivores can influence communities and population resilience through these differences in reproductive output. While the impact of removal of flowers on overall plant reproduction has been studied numerous times (See McCall \& Irwin, 2006), the impact of this removal specifically on pollination or pollinator visitation is rarely studied. Out of the 29 papers that examined the impact of florivory on pollination found in this review, only one examined complete florivory (Sutter \& Albrecht, 2016). Changes in plant population and community dynamics due to changes in reproduction have the potential to impact pollinators; for instance, patches with more flowers tend to attract more pollinators (Lazaro \& Totland, 2010). Pollinators in turn interact with plants to determine reproductive output. Therefore, the indirect interactions between herbivores and pollinators fosters even further co-evolutionary processes such that plants not only sufficiently compensate for lost reproductive structures due to herbivores, but also to produce flowers of quality and quantity sufficient to attract pollinators. This interaction requires further research into the implications of complete florivory on plant compensation, pollination, and reproduction.

Incomplete florivory can also impact both pollination and plant reproduction. Incomplete florivory can result in flowers that are less attractive to pollinators despite offering the same reward. (Mothershead \& Marquis, 2000). Pollinators can use visual cues such as floral symmetry to choose between flowers (Rodríguez et al., 2004). A loss of symmetry can result in decreased visitation (McCall, 2010). When other cues are more important, there may be no effect of incomplete florivory (Malo, Leirana-Alcocer \& Parra-Tabla, 2001) and plants can mitigate or eliminate the negative effects of herbivory on floral display by reproducing via selfpollination (with or without pollinators) in some cases including several species in this systematic review (e.g. Cardel \& Koptur, 2010). While this review focused on animal-pollinated plants, many plants are not wholly reliant on animals for reproduction (Culley, Weller \& Sakai, 2002). However, since animal pollination frequently increases plant fitness (Klein et al., 2007; Cardel \& Koptur, 2010; Jorge, Loureiro \& Castro, 2015) this strategy may only limit the effects of incomplete florivory as opposed to eliminating them. In addition, the actual presence of florivores in flowers can deter pollinators. For example, Canela and Sazima (2003) found that florivorous crabs not only decreased attraction of flowers to pollinators through damage but that pollinators were less likely to visit flowers while the crabs were present. All of the 29 studies we found that examined the impact of florivory on pollination examined partial florivory. In most studies, partial florivory was found to decrease pollinator visitation or pollen deposition as well as plant reproduction (fruit set or seed set). By decreasing pollinator visitation, incomplete florivory can indirectly decrease plant reproduction (via pollen limitation). As with complete florivory decreases in reproduction can impact population dynamics, while indirect effects on pollinators can drive the coevolutionary arms race between herbivores and plants that might not

PeerJ reviewing PDF | (2019:10:42005:2:0:NEW 27 Mar 2020) 
260

261

262

263

264

265

266

267

268

269

270

271

272

273

274

275

276

277

278

279

280

281

282

283

284

285

286

287

288

289

290

291

292

293

294

295

296

297

298

299

300

301

302

303

otherwise occur under the limited damage of incomplete florivory (that is, florivory that keeps ovules and stigmas intact).

\section{Effects of Vegetative Herbivory on Pollination}

While direct damage to floral tissue is the most common way to examine the effects of herbivores on pollinators (Fig. 4), damage to vegetative tissue also had indirect effects on floral attributes. The main mechanism that folivory, root damage and stem damage impact pollinators is through decreasing both resources and the ability for plants to produce resources (Mothershead \& Marquis, 2000). By decreasing the amount of photosynthetic and absorptive area available to a plant or siphoning off xylem or phloem, fewer or smaller flowers may be produced (Mothershead \& Marquis, 2000; Hambäck, 2001; Hladun \& Adler, 2009). These flowers may be less attractive to pollinators (Mothershead \& Marquis, 2000) or theoretically be less fertile, producing fewer seeds. While plants are also able to compensate for vegetative damage, resources are often allocated to regrowth instead of reproduction and so vegetative damage can still decrease fitness (Pratt et al., 2005; Garcia \& Eubanks, 2019). Root herbivory can also change how the plant interacts with aboveground herbivores and mutualists (Barber et al., 2015). For instance, root herbivory can decrease aboveground herbivory and increase the nectar in extrafloral nectaries (Hladun \& Adler, 2009; Soler et al., 2012).

While folivory, root herbivory, and stem damage can decrease reproductive output (Mutikainen \& Delph, 1996; Lehtilä \& Strauss, 1999; Pratt et al., 2005; Lopez-Toledo et al., 2018 ), it is less clear whether they impact pollinators or pollination. Folivory, root damage, and stem damage were found to negatively impact several floral traits, as well as pollinator visitation and reproduction (Mutikainen \& Delph, 1996; Strauss, Conner \& Rush, 1996; Mothershead \& Marquis, 2000; Hambäck, 2001; Arceo-Gómez, Parra-Tabla \& Navarro, 2009; Hladun \& Adler, 2009; Barber \& Gorden, 2013; Sasal, Farji-Brener \& Raffaele, 2017). Folivory was found to have negative effects on most floral traits including floral morphology, abundance, and phenology. Stem damage was found to have a negative effect on floral morphology, size, and abundance while root herbivory affected floral abundance and pollen production. However, the number of studies that found each of these effects is low and each type of vegetative damage was also frequently observed to have no effect on each of these respective traits and occasionally a positive effect. It is also possible that plants are better able to compensate for or resist vegetative damage such that there will be no change in floral display or reproduction. For instance, (as with incomplete florivory) plants may switch to self-pollination if floral display is compromised or pollination is limited.

While it is clear that vegetative damage can impact pollination and plant reproduction, vegetative damage was also frequently observed to have no effect. This lack of effect may be only representative of small sample size and more studies would find the proportions more similar to what is found with florivory. However, finding fewer studies may be because few studies examined different types of herbivory (Fig. 5) or different taxa simultaneously (Fig. 4; Supplemental Table S3). The same herbivore can feed on multiple tissues (at the same time or switching ontogenetically; e.g. Lucas-Barbosa et al., 2016) or multiple herbivores can feed on different tissues (or even the same tissue) simultaneously (e.g. Barber, Adler \& Bernardo, 2011). Therefore, it is difficult to determine whether different types of herbivory may act synergistically or if they interfere with each other (as seen between root herbivory and 
304

305

306

307

308

309

310

311

312

313

314

315

316

317

318

319

320

321

322

323

324

325

326

327

328

329

330

331

332

333

334

335

336

337

338

339

340

341

342

343

344

345

346

347

aboveground herbivory in Barber et al. 2015). The larger proportion of neutral effects of vegetative herbivory on pollination may only be an indication of not considering damage to all types of vegetative tissues.

This lack of directly comparing individual species of herbivores is one weakness of some of the papers included in this study. While comparing the effects of a broader taxonomic scope or community of herbivores or pollinators is good for comparing the net outcomes of interactions, the exact effects and net outcomes of individual species is lost. More research that examine specific species, especially multiple specific species could help illuminate these differences. This is particularly prevalent with how few studies examined individual pollinator species compared to those that studied the entire community (Fig. 4). In contrast, the indirect pathway from vegetative damage to changes in pollination may simply be more heavily regulated by plant physiological responses with plants preferentially allocating resources to reproduction over regrowth (Fig. 2). Considering multiple species in this case may not change this result. Regardless, the small sample size makes any conclusions about the relative proportion of studies to find significant or neutral effects of vegetative damage dubious.

Integrating the Effects of Floral and Vegetative Herbivory

Vegetative herbivory can impact plant populations and communities through plant reproduction, but the role of the indirect effect of vegetative herbivory on pollinators and the role of pollinators in driving co-evolution between plants and non-floral herbivores is less distinct than when examining florivores. In order to determine the relative effect of direct and indirect damage to floral tissue on pollination, these two mechanisms need to be compared more frequently. In this systematic review, only three studies examined the direct and indirect effects of herbivory on floral display and pollination (Fig. 5). Specifically, these three studies compared florivory to folivory. Lucas-Barbosa et al. (2013) examined the behaviour of pollinators of Brassica nigra in response to the specialist caterpillar Pieris brassicae. Pieris brassicae feeds on the leaves of $B$. nigra at a younger stage, and progress later to consuming flowers. Therefore, while examining damage to two types of tissues, the damage was done by the same individuals. They found there was no effect of $P$. brassicae on pollinators during the folivory stage, while there was an effect at the florivory stage. In a study with the same system by many of the same authors (Lucas-Barbosa et al. 2016) where the effect of damage to vegetative and floral tissues on floral volatiles detected by pollinators was studied, neither folivory nor florivory influenced pollinators.

Finally, Mothershead and Marquis (2000) examined the effect of artificial damage to both leaves and buds to the floral traits and seed set of Oenothera macrocarpa in the presence and absence of supplemental hand pollination. Both folivory and florivory affected floral traits (both morphology and size), that in turn impacted pollination and seed set. Folivory was not found to directly reduce seed set through reduced floral resources, but rather only indirectly through floral morphology. However, floral damage decreased fruit set (68\% reduction) more than foliar damage ( $18 \%$ reduction). While two of these studies point towards florivory having a greater impact on pollination than folivory, two of three studies is not sufficient sample size to determine the relative importance of direct (florivory) over indirect (vegetative herbivory) damage. Only multiple studies that directly compare florivory and other types of herbivory within the same system will be sufficient to determine their relative importance.

Peer) reviewing PDF | (2019:10:42005:2:0:NEW 27 Mar 2020) 
348

349

350

351

352

353

354

355

356

357

358

359

360

361

362

363

364

365

366

367

368

369

370

371

372

373

374

375

376

377

378

379

380

381

382

383

384

385

386

387

388

389

390

Similarly, the larger proportion of papers that examined florivory over other forms of herbivory (Fig. 5) or the greater proportion of studies with a negative impact on pollination or reproduction due to florivory is not sufficient to make the claim that florivory has a greater impact on pollination than damage to vegetative tissue. Florivory is the more obvious choice when studying the effects of herbivory on pollination and so a bias in papers towards florivory is expected. Similarly, the sample size of studies that examine any other form of herbivory is particularly low, and so proportions are not necessarily representative. While it is intuitive and may be true that direct damage to floral tissue has a greater impact than indirect damage on pollination, there is not sufficient evidence to make this claim

Some herbivores act as both herbivores and pollinators at different ontogenetic stages (Lucas-Barbosa et al., 2016). This type of switch is commonly seen in pollinating insects with a herbivorous larval form (Nakazawa, 2015). However, only a single species, the B. nigra specialist $P$. brassicae, was examined as both a herbivore and a pollinator. Furthermore, $P$. brassicae was only examined as both herbivore and pollinator of $B$. nigra in a single study (Lucas-Barbosa et. Al 2016), although it was also used as a herbivore in Lucas-Barbosa et al. (2013) and as a pollinator in Rusman et al. (2019). The intricate relationship and co-evolution between species that change between negative and positive interactions is not one that is unstudied (see Nakazawa, 2015). Strategies that reduce the impact of herbivores at an early stage that might negatively impact the later production of floral resources would be beneficial to both plant and herbivore in this case, even more so than with species that do not share this relationship. However, clearly the net outcome of early stage herbivory on plant reproduction and late stage pollination is lacking within the literature.

\section{Effects of Damage to Unspecified Tissue on Pollination}

The joint impact of damage to multiple tissues can be extended to the effects of herbivores that do not have a plant tissue preference. Most studies examined damage to specific tissues; however, a number of studies examined damage to unspecified tissues, representing both direct and indirect mechanisms that are not differentiated. Grazing encompasses possible damage to flowers, leaves, and stems. Grazing is of particular import because of its potential severity and anthropogenic causes. The agricultural industry plays a large role in the impact humans have in creating disturbed ecosystems (Kitzes et al., 2008). Most studies that examined direct or indirect damage to floral tissue used insects as focal herbivores; those that looked at unspecified damage exclusively used mammals (Fig. 4). While studies frequently look at grazing by large mammals such as deer and cattle at a community level-examining the plant, or even floral diversity of a system (Olff \& Ritchie, 1998; Kohyani et al., 2008; Herrero-Jáuregui \& Oesterheld, 2018), it is rare for these studies to further examine the pollination consequences of grazing. Studies that examined grazing reported some negative effect of grazing on plant reproduction or pollinator visitation. Grazing also impacted floral morphology, number, phenology, and pollen production, but the mechanisms were not clearly reported in primary studies. By studying the synergistic effects of multiple effect pathways, we can better understand how grazing can impact vegetation.

Other Interactions

Peer) reviewing PDF | (2019:10:42005:2:0:NEW 27 Mar 2020) 
While the indirect effects of herbivory on pollination are the focus of this review; there are other ways in which pollinators and herbivores interact. For instance, there are direct interactions between herbivores and pollinators where the presence of herbivores actively deters pollinators from approaching flowers (Canela \& Sazima, 2003). Additionally, pollination may impact herbivory by facilitating the successful reproduction of herbivore plant hosts. However, these types of interactions are neither included in this review nor the conceptual framework.

\section{Conclusions}

Both direct and indirect damage to floral tissue can impact pollination and plant reproduction. However, direct and indirect damage to floral tissue is rarely examined in concert, nor are damage by different herbivores. The relative importance of the direct and indirect mechanisms and synergistic effects of multiple herbivores have important implications for ecological resilience and stability in evolutionary processes. However, this relative importance is almost never examined with the focus lying on each type and each herbivore individually. The indirect effect of herbivores on pollinators can mediate co-evolutionary processes between plants and herbivores and plants and pollinators. The collection of herbivores that interact with plants can include species that feed on all types of tissue either simultaneously or temporally separated that the plant then integrates into growth, allocation, defense, or phenology. This in turn can impact pollinators and pollination, making these two plant-animal interactions intimately linked.

\section{Acknowledgements}

CJL was funded by an NSERC DG. SH was funded by York University.

\section{References}

Adler LS. 2000. Alkaloid uptake increases fitness in a hemiparasitic plant via reduced herbivory and increased pollination. The American Naturalist 156:92-99. DOI: 10.1086/303374.

Adler LS, Karban R, Strauss SY. 2001. Direct and indirect effects of alkaloids on plant fitness Via herbivory and pollination. Ecology 82:2032-2044.

Agrawal AA, Rudgers JA, Botsford LW, Cutler D, Gorin JB, Lundquist CJ, Spitzer BW, Swann AL. 2000. Benefits and constraints on plant defense against herbivores: spines influence the legitimate and illegitimate flower visitors of yellow star thistle, Centaurea solstitialis L. (Asteraceae). The Southwestern Naturalist 45:1-5. DOI: 10.2307/3672545.

Åhman I, Lehrman A, Ekbom B. 2009. Impact of herbivory and pollination on performance and competitive ability of oilseed rape transformed for pollen beetle resistance. Arthropod-Plant Interactions 3:105-113. DOI: 10.1007/s11829-009-9061-z.

Arceo-Gómez G, Parra-Tabla V, Navarro J. 2009. Changes in sexual expression as result of defoliation and environment in a monoecious shrub in Mexico: implications for pollination. Biotropica 41:435-441. DOI: 10.1111/j.1744-7429.2009.00502.x.

Aschero V, Vázquez DP. 2009. Habitat protection, cattle grazing and density-dependent reproduction in a desert tree. Austral Ecology 34:901-907. DOI: 10.1111/j.14429993.2009.01997.x. 
434

435

436

437

438

439

440

441

442

443

444

445

446

447

448

449

450

451

452

453

454

455

456

457

458

459

460

461

462

463

464

465

466

467

468

469

470

471

472

473

474

475

476

477

Avila-Sakar G, Simmers SM, Stephenson AG. 2003. The interrelationships among leaf damage, anther development, and pollen production in Cucurbita pepo ssp. texana (Cucurbitaceae). International Journal of Plant Sciences 164:395-404. DOI: 10.1086/374196.

Barber NA, Gorden NLS. 2013. How do belowground organisms influence plant-pollinator interactions? Journal of Plant Ecology 8:1-11. DOI: 10.1093/jpe/rtu012.

Barber NA, Milano NJ, Kiers ET, Theis N, Bartolo V, Hazzard R V., Adler LS. 2015. Root herbivory indirectly affects above- and below-ground community members and directly reduces plant performance. Journal of Ecology 103:1509-1518. DOI: 10.1111/13652745.12464.

Benning JW, Moeller DA. 2019. Maladaptation beyond a geographic range limit driven by antagonistic and mutualistic biotic interactions across an abiotic gradient. Evolution:1-16. DOI: $10.1111 /$ evo.13836.

Boivin T, Doublet V, Candau JN. 2019. The ecology of predispersal insect herbivory on tree reproductive structures in natural forest ecosystems. Insect Science 26:182-198. DOI: 10.1111/1744-7917.12549.

Borrett SR, Whipple SJ, Patten BC. 2010. Rapid development of indirect effects in ecological networks. Oikos 119:1136-1148. DOI: 10.1111/j.1600-0706.2009.18104.x.

Botto-Mahan C, Ramírez PA, Ossa CG, Medel R, Ojeda-Camacho M, González A V. 2011. Floral herbivory affects female reproductive success and pollinator visitation in the perennial herb Alstroemeria ligtu (Alstroemeriaceae). International Journal of Plant Sciences 172:1130-1136. DOI: 10.1086/662029.

Brody AK. 1997. Effects of pollinators, herbivores, and seed predators on flowering phenology. Ecology 78:1624-1631. DOI: 10.1890/0012-9658(1997)078\{[\}1624:EOPHAS]2.0.CO;2.

Brody AK, Irwin RE. 2012. When resources don't rescue: flowering phenology and species interactions affect compensation to herbivory in Ipomopsis aggregata. Oikos 121:14241434. DOI: 10.1111/j.1600-0706.2012.20458.x.

Buchanan AL. 2014. Effects of damage and pollination on sexual and asexual reproduction in a flowering clonal plant. Plant Ecology 216:273-282. DOI: 10.1007/s11258-014-0434-8.

Caballero P, Ossa CG, Gonzáles WL, González-Browne C, Astorga G, Murúa MM, Medel R. 2013. Testing non-additive effects of nectar-robbing ants and hummingbird pollination on the reproductive success of a parasitic plant. Plant Ecology 214:633-640. DOI: 10.1007/s11258-013-0195-9.

Canela MBF, Sazima M. 2003. Florivory by the crab Armases angustipes (Grapsidae) influences hummingbird visits to Aechmea pectinata (Bromeliaceae). Biotropica 35:289294. DOI: 10.1111/j.1744-7429.2003.tb00287.x.

Cardel YJ, Koptur S. 2010. Effects of florivory on the pollination of flowers: an experimental field study with a perennial plant. International Journal of Plant Sciences 171:283-292. DOI: 10.1086/650154.

Cares-Suárez R, Poch T, Acevedo RF, Acosta-Bravo I, Pimentel C, Espinoza C, Cares RA, Muñoz P, González A V, Botto-Mahan C. 2011. Do pollinators respond in a dosedependent manner to flower herbivory?: an experimental assessment in Loasa tricolor (Loasaceae). Gayana. Botánica 68:176-181. DOI: 10.4067/S0717-66432011000200007.

Cariveau DP, Norton AP. 2014. Direct effects of a biocontrol agent are greater than indirect effects through flower visitors for the alien plant Dalmatian toadflax (Linaria dalmatica: 
478

479

480

481

482

483

484

485

486

487

488

489

490

491

492

493

494

495

496

497

498

499

500

501

502

503

504

505

506

507

508

509

510

511

512

513

514

515

516

517

518

519

520

521

Scrophulariaceae). Biological Invasions 16:1951-1960. DOI: 10.1007/s10530-013-0638-1. Chalcoff VR, Lescano MN, Devegili AM. 2019. Do novel interactions with local fauna have reproductive consequences for exotic plants? A case study with thistles, ants, aphids, and pollinators. Plant Ecology 220:125-134. DOI: 10.1007/s11258-019-00907-2.

Chen M. 2008. Inducible direct plant defense against insect herbivores : A review. Insect Science 15:101-114.

Culley TM, Weller SG, Sakai AK. 2002. The evolution of wind pollination in angiosperms. Trends in Ecology \& Evolution 17:361-369.

Cunningham SA. 1995. Ecological constraints on fruit initiation by Calyptrogyne ghiesberghtiana (Arecaceae): floral herbivory, pollen availability, and visitation by pollinating bats. American Journal of Botany 82:1527-1536.

Danderson CA, Molano-Flores B. 2010. Effects of herbivory and inflorescence size on insect visitation to Eryngium yuccifolium (Apiaceae) a prairie plant. The American Midland Naturalist 163:234-246. DOI: 10.1674/0003-0031-163.1.234.

Enri SR, Probo M, Farruggia A, Lanore L, Blanchetete A, Dumont B. 2017. A biodiversityfriendly rotational grazing system enhancing flower-visiting insect assemblages while maintaining animal and grassland productivity. Agriculture, Ecosystems and Environment 241:1-10. DOI: 10.1016/j.agee.2017.02.030.

García-cervigón, Al, Iriondo JM, Linares JC, and Olano JM. 2016. Disentangling facilitation along the life cycle: Impacts of plant - plant interactions at vegetative and reproductive stages in a Mediterranean forb. Frontiers in Plant Science 7:1-11. DOI: 10.3389/fpls.2016.00129.

Garcia LC, Eubanks MD. 2019. Overcompensation for insect herbivory: a review and metaanalysis of the evidence. Ecology 100:02585. DOI: 10.1002/ecy.2585.

Garrido P, Mårell A, Öckinger E, Skarin A, Jansson A, Thulin CG. 2019. Experimental rewilding enhances grassland functional composition and pollinator habitat use. Journal of Applied Ecology 56:946-955. DOI: 10.1111/1365-2664.13338.

Hambäck PA. 2001. Direct and indirect effects of herbivory: Feeding by spittlebugs affects pollinator visitation rates and seedset of Rudbeckia hirta. Ecoscience 8:45-50. DOI: 10.1080/11956860.2001.11682629.

Hawkes C V., Sullivan JJ. 2001. The impact of herbivory on plants in different resource conditions: a meta-analysis. Ecology 82:2045-2058.

Heil M. 2008. Indirect defence via tritrophic interactions. New Phytologist 178:41-61. DOI: 10.1111/j.1469-8137.2007.02330.x.

Herrero-Jáuregui C, Oesterheld M. 2018. Effects of grazing intensity on plant richness and diversity: a meta-analysis. Oikos 127:757-766. DOI: 10.1111/oik.04893.

Hladun KR, Adler LS. 2009. Influence of leaf herbivory, root herbivory, and pollination on plant performance in Cucurbita moschata. Ecological Entomology 34:144-152. DOI: 10.1111/j.1365-2311.2008.01060.x.

Huth CJ, Pellmyr O. 1997. Non-random fruit retention in Yucca filamentosa: consequences for an obligate mutualism. Oikos 78:576-584. DOI: 10.2307/3545620.

Jorge A, Loureiro J, Castro S. 2015. Flower biology and breeding system of Salvia sclareoides Brot. (Lamiaceae). Plant Systematics and Evolution 301:1485-1497. DOI: 10.1007/s00606-014-1169-7. 
522

523

524

525

526

527

528

529

530

531

532

533

534

535

536

537

538

539

540

541

542

543

544

545

546

547

548

549

550

551

552

553

554

555

556

557

558

559

560

561

562

563

564

565

Juenger T, Bergelson J. 1997. Pollen and resource limitation of compensation to herbivory in scarlet gilia, Ipomopsis aggregata. Ecology 78:1684-1695.

Kelly D, Ladley JJ, Robertson AW, Crowfoot L. 2008. Flower predation by Zelleria maculata (Lepidoptera) on Peraxilla mistletoes: effects of latitude and fragmentation, and impact on fruit set. New Zealand Journal of Ecology 32:186-196.

Kitzes J, Wackernagel M, Loh J, Peller A, Goldfinger S, Cheng D, Tea K. 2008. Shrink and share: humanity's present and future Ecological Footprint. Philosophical Transactions of the Royal Society B: Biological Sciences 363:467-475. DOI: 10.1098/rstb.2007.2164.

Klein AM, Vaissière BE, Cane JH, Steffan-Dewenter I, Cunningham SA, Kremen C, Tscharntke T. 2007. Importance of pollinators in changing landscapes for world crops. Proceedings of the Royal Society B: Biological Sciences 274:303-313. DOI: 10.1098/rspb.2006.3721.

Knight TM. 2004. The effects of herbivory and pollen limitation on a declining population of Trillium grandiflorum. Ecological Applications 14:915-928. DOI: 10.1890/03-5048.

Kohyani PT, Bossuyt B, Bonte D, Hoffmann M. 2008. Grazing as a management tool in dune grasslands: Evidence of soil and scale dependence of the effect of large herbivores on plant diversity. Biological Conservation 141:1687-1694. DOI: 10.1016/j.biocon.2008.04.010.

Krupnick GA, Weis AE. 1999. The effect of floral herbivory on male and female reproductive success in Isomeris arborea. Ecology 80:135-149. DOI: 10.1890/00129658(1999)080[0135:TEOFHO]2.0.CO;2.

Krupnick GA, Weis AE, Campbell DR. 1999. The consequences of floral herbivory for pollinator service to Isomeris arborea. Ecology 80:125-134.

Lazaro A, Totland O. 2010. Local floral composition and the behaviour of pollinators: attraction to and foraging within experimental patches. Ecological Entomology 35:652-661. DOI: 10.1111/j.1365-2311.2010.01223.x.

Leavitt H, Robertson IC. 2006. Petal herbivory by chrysomelid beetles (Phyllotreta sp.) is detrimental to pollination and seed production in Lepidium papilliferum (Brassicaceae). Ecological Entomology 31:657-660. DOI: 10.1111/j.1365-2311.2006.00820.x.

Lehtilä K, Strauss SY. 1999. Effects of foliar herbivory on male and female reproductive traits of wild radish, Raphanus raphanistrum. Ecology 80:116-124. DOI: 10.1890/00129658(1999)080[0116:EOFHOM]2.0.CO;2.

Liao K, Gituru RW, Guo YH, Wang QF. 2013. Effects of floral herbivory on foraging behaviour of bumblebees and female reproductive success in Pedicularis gruina (Orobanchaceae). Flora 208:562-569. DOI: 10.1016/j.flora.2013.08.007.

Lohman DJ, Zangerl AR, Berenbaum MR. 1996. Impact of floral herbivory by parsnip webworm (Oecophoridae: Depressaria pastinacella Duponchel ) on pollination and fitness of wild parsnip (Apiaceae: Pastinaca sativa L.). The American Midland Naturalist 136:407-412.

Lopez-Toledo L, Perez-Decelis A, Macedo-Santana F, Cuevas E, Endress BA. 2018. Chronic leaf harvesting reduces reproductive success of a tropical dry forest palm in northern Mexico. PLoS ONE 13:1-16. DOI: 10.1371/journal.pone.0205178.

Louthan A, Valencia E, Martins DJ, Guy T, Goheen J, Palmer T, Doak D. 2019. Large mammals generate both top-down effects and extended trophic cascades on floral-visitor assemblages. Journal of Tropical Ecology 35:185-198. DOI: 10.1017/S0266467419000142.

Peer] reviewing PDF | (2019:10:42005:2:0:NEW 27 Mar 2020) 
566 Lucas-Barbosa D. 2016. Integrating studies on plant-pollinator and plant-herbivore interactions.

567

568

569

570

571

572

573

574

575

576

577

578

579

580

581

582

583

584

585

586

587

588

589

590

591

592

593

594

595

596

597

598

599

600

601

602

603

604

605

606

607

608

609
Trends in Plant Science 21:125-133. DOI: 10.1016/j.tplants.2015.10.013.

Lucas-Barbosa D, Van Loon JJA, Dicke M. 2011. The effects of herbivore-induced plant volatiles on interactions between plants and flower-visiting insects. Phytochemistry 72:1647-1654. DOI: 10.1016/j.phytochem.2011.03.013.

Lucas-Barbosa D, van Loon JJA, Gols R, van Beek TA, Dicke M. 2013. Reproductive escape: annual plant responds to butterfly eggs by accelerating seed production. Functional Ecology 27:245-254. DOI: 10.1111/1365-2435.12004.

Lucas-Barbosa D, Sun P, Hakman A, van Beek TA, van Loon JJA, Dicke M. 2016. Visual and odour cues: plant responses to pollination and herbivory affect the behaviour of flower visitors. Functional Ecology 30:431-441. DOI: 10.1111/1365-2435.12509.

Malo JE, Leirana-Alcocer J, Parra-Tabla V. 2001. Population fragmentation, florivory, and the effects of flower morphology alterations on the pollination success of Myrmecophila tibicinis (Orchidaceae). Biotropica 33:529-534. DOI: 10.1111/j.1744-7429.2001.tb00207.x.

McCall AC. 2010. Does dose-dependent petal damage affect pollen limitation in an annual plant? Botany 88:601-606. DOI: 10.1139/B10-032.

McCall AC, Irwin RE. 2006. Florivory: The intersection of pollination and herbivory. Ecology Letters 9:1351-1365. DOI: 10.1111/j.1461-0248.2006.00975.x.

Michalet R, Chen SY, An LZ, Wang XT, Wang YX, Guo P, Ding CC, Xiao S. 2015. Communities: Are they groups of hidden interactions? Journal of Vegetation Science 26:207-218. DOI: 10.1111/jvs.12226.

Missagia CCC, Alves MAS. 2017. Florivory and floral larceny by fly larvae decrease nectar availability and hummingbird foraging visits at Heliconia (Heliconiaceae) flowers. Biotropica 49:13-17. DOI: 10.1111/btp.12368.

Moranz RA, Fuhlendorf SD, Engle DM. 2014. Making sense of a prairie butterfly paradox: the effects of grazing, time since fire, and sampling period on regal fritillary abundance. Biological Conservation 173:32-41. DOI: 10.1016/j.biocon.2014.03.003.

Mothershead K, Marquis RJ. 2000. Fitness impact of herbivore through indirect effects on plantpollinator interactions in Oenothera macrocarpa. Ecology 81:30-40. DOI: 10.1890/00129658(2000)081[0030:FIOHTI]2.0.CO;2.

Motzke I, Tscharntke T, Wanger TC, Klein AM. 2015. Pollination mitigates cucumber yield gaps more than pesticide and fertilizer use in tropical smallholder gardens. Journal of Applied Ecology 52:261-269. DOI: 10.1111/1365-2664.12357.

Munguía-Rosas MA, Arias LM, Jurado-Dzib SG, Mezeta-Cob CR, Parra-Tabla V. 2015. Effects of herbivores and pollinators on fruit yield and survival in a cleistogamous herb. Plant Ecology 216:517-525. DOI: 10.1007/s11258-015-0455-y.

Mutikainen P, Delph LF. 1996. Effects of herbivory on male reproductive success in plants. Oikos 75:353-358.

Nakazawa T. 2015. Ontogenetic niche shifts matter in community ecology: a review and future perspectives. Population Ecology 57:347-354. DOI: 10.1007/s10144-014-0448-z.

Ohgushi T. 2005. Indirect interaction webs: herbivore-induced effects through trait change in plants. Annual Review of Ecology, Evolution, and Systematics 36:81-105. DOI:

10.1146/annurev.ecolsys.36.091704.175523.

Olff H, Ritchie ME. 1998. Effects of herbivores on grassland plant diversity. Trends in Ecology 
610

611

612

613

614

615

616

617

618

619

620

621

622

623

624

625

626

627

628

629

630

631

632

633

634

635

636

637

638

639

640

641

642

643

644

645

646

647

648

649

650

651

652

653

and Evolution 13:261-265. DOI: 10.1016/S0169-5347(98)01364-0.

Olson DM, Dinerstein E, Wikramanayake ED, Burgess ND, Powell GVN, Underwood EC, D'Amico JA, Itoua I, Strand HE, Morrison JC, Loucks CJ, Allnut TF, Ricketts TH, Kura Y, Lamoreux JF, Wettengel WW, Hedao P, Kassem KR. 2001. Terrestrial Ecoregions of the World: A New Map of Life on Earth. BioScience 51:933-938.

Pilosof S, Porter MA, Pascual M, Kéfi S. 2017. The multilayer nature of ecological networks. Nature Ecology \& Evolution 1:1-35. DOI: 10.1038/s41559-017-0101.

Pratt PD, Rayamajhi MB, Van TK, Center TD. 2005. Herbivory alters resource allocation and compensation in the invasive tree Melaleuca quinquenervia. Ecological Entomology 30:316-326.

Proulx SR, Promislow DEL, Phillips PC. 2005. Network thinking in ecology and evolution. Trends in Ecology and Evolution 20:345-353. DOI: 10.1016/j.tree.2005.04.004.

QGIS Development Team. 2019. QGIS Geographic Information System. Open Source Geospatial Foundation Project. http://qgis.osgeo.org.

Rodríguez I, Gumbert A, De Ibarra NH, Kunze J, Giurfa M. 2004. Symmetry is in the eye of the "beeholder": Innate preference for bilateral symmetry in flower-naïve bumblebees. Naturwissenschaften 91:374-377. DOI: 10.1007/s00114-004-0537-5.

Rusman Q, Poelman EH, Nowrin F, Polder G, Lucas-Barbosa D. 2019. Floral plasticity: Herbivore-species-specific-induced changes in flower traits with contrasting effects on pollinator visitation. Plant Cell and Environment 42:1882-1896. DOI: 10.1111/pce.13520.

Ruttan A, Lortie CJ. 2013. A systematic review of the attractant-decoy and repellent-plant hypotheses: Do plants with heterospecific neighbours escape herbivory? Journal of Plant Ecology 8:337-346. DOI: 10.1093/jpe/rtu030.

Santangelo JS, Thompson KA, Johnson MTJ. 2019. Herbivores and plant defences affect selection on plant reproductive traits more strongly than pollinators. Journal of Evolutionary Biology 32:4-18. DOI: 10.1111/jeb.13392.

Sasal Y, Farji-Brener A, Raffaele E. 2017. Fire modulates the effects of introduced ungulates on plant-insect interactions in a Patagonian temperate forest. Biological Invasions 19:24592475. DOI: $10.1007 / \mathrm{s} 10530-017-1455-8$.

Scopece G, Frachon L, Cozzolino S. 2019. Do native and invasive herbivores have an effect on Brassica rapa pollination? Plant Biology 21:927-934. DOI: 10.1111/plb.12985.

Sõber V, Moora M, Teder T. 2010. Florivores decrease pollinator visitation in a self-incompatible plant. Basic and Applied Ecology 11:669-675. DOI: 10.1016/j.baae.2010.09.006.

Sõber V, Teder T, Moora M. 2009. Contrasting effects of plant population size on florivory and pollination. Basic and Applied Ecology 10:737-744. DOI: 10.1016/j.baae.2009.06.003.

Soler R, van der Putten WH, Harvey JA, Vet LEM, Dicke M, Bezemer TM. 2012. Root herbivore effects on aboveground multitrophic interactions: patterns, processes and mechanisms. Journal of Chemical Ecology 38:755-767. DOI: 10.1007/s10886-012-0104-z.

Strauss SY, Conner JK, Rush SL. 1996. Foliar herbivory affects floral characters and plant attractiveness to pollinators: implications for male and female plant fitness. The American Naturalist 147:1098-1107.

Suárez-Esteban A, Delibes M, Fedriani JM. 2014. Unpaved roads disrupt the effect of herbivores and pollinators on the reproduction of a dominant shrub. Basic and Applied Ecology 15:524-533. DOI: 10.1016/j.baae.2014.08.001.

Peer] reviewing PDF | (2019:10:42005:2:0:NEW 27 Mar 2020) 
654 Suárez LH, Gonzáles WL, Gianoli E. 2009. Foliar damage modifies floral attractiveness to 655 pollinators in Alstroemeria exerens. Evolutionary Ecology 23:545-555. DOI:

$656 \quad 10.1007 / \mathrm{s} 10682-008-9254-4$.

657 Sutter L, Albrecht M. 2016. Synergistic interactions of ecosystem services: pest control boosts $658 \quad$ crop yield increase through insect pollination. Proceedings of the Royal Society B. DOI: $659 \quad 10.1098 /$ rspb.2015.2529.

660 Torres I, Salinas L, Lara C, Castillo-Guevara C. 2008. Antagonists and their effects in a 661 hummingbird-plant interaction: Field experiments. Ecoscience 15:65-72. DOI:

662 10.2980/1195-6860(2008)15[65:AATEIA]2.0.CO;2.

663 Tsuji K, Dhami MK, Cross DJR, Rice CP, Romano NH, Fukami T. 2016. Florivory and pollinator 664 visitation: A cautionary tale. AoB PLANTS 8. DOI: 10.1093/aobpla/plw036.

665

666

667

668

669

670

671

672

673

674

675

676

677

678

679

680

681

Valdivia CE, Niemeyer HM. 2005. Reduced maternal fecundity of the high Andean perennial herb Alstroemeria umbellata (Alstroemeriaceae) by aphid herbivory. New Zealand Journal of Ecology 29:321-324.

Vallius E, Salonen V. 2006. Allocation to reproduction following experimental defoliation in Platanthera bifolia (Orchidaceae). Plant Ecology 183:291-304. DOI: 10.1007/s11258-0059040-0.

Vazquez DP, Simberloff D. 2004. Indirect effects of an introduced ungulate on pollination and plant reproduction. Ecological Monographs 74:281-308.

Vulliamy B, Potts SG, Willmer PG. 2006. The effects of cattle grazing on plant-pollinator communities in a fragmented Mediterranean landscape. Oikos 114:529-543. DOI: 10.1111/j.2006.0030-1299.14004.x.

Wise MJ, Cummins JJ, De Young C. 2008. Compensation for floral herbivory in Solanum carolinense: Identifying mechanisms of tolerance. Evolutionary Ecology 22:19-37. DOI: 10.1007/s10682-007-9156-x.

Zangerl AR, Berenbaum MR. 2009. Effects of florivory on floral volatile emissions and pollination success in the wild parsnip. Arthropod-Plant Interactions 3:181-191. DOI: 10.1007/s11829-009-9071-x.

682 
Figure 1

PRISMA diagram for the progression of papers included in the analyses.

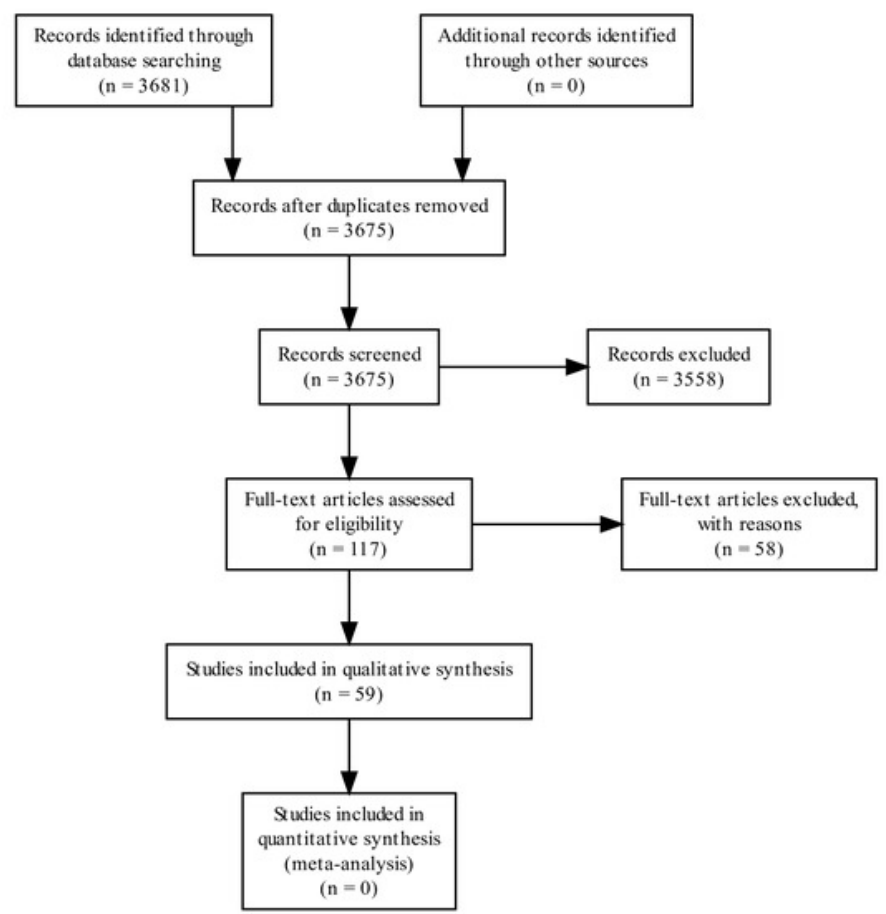




\section{Figure 2}

Mechanisms of damage by herbivores that can impact pollination and therefore seed set.

Solid lines represent direct interactions and dotted lines indirect interactions. The two main pathways are direct (direct damage to floral tissue influences pollinators; shown lighter in orange) and indirect (damage to vegetative tissue indirectly effects floral traits; shown in darker in blue). Lines and boxes in black represent interactions and steps shared by both pathways. The thick dotted lines represent the net indirect interaction of plant damage on pollinators (and pollination) that was the focus of this review.

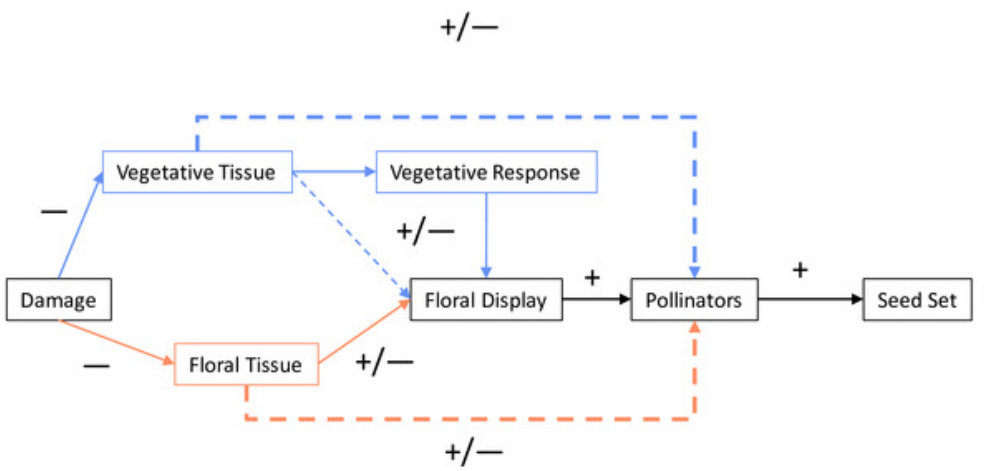




\section{Figure 3}

Geographical distribution of studies ( $N=56 ; 3$ studies had no geographic information) across biomes that examined the impact of both herbivores and pollinators.

Studies spanned over 20 countries and 11 biomes. Biomes were generated from Terrestrial Ecoregions of the World, originating from the World Wildlife Fund (Olson et al. 2001; CC BYNC 3.0 https://creativecommons.org/licenses/by-nc/3.0/ ).

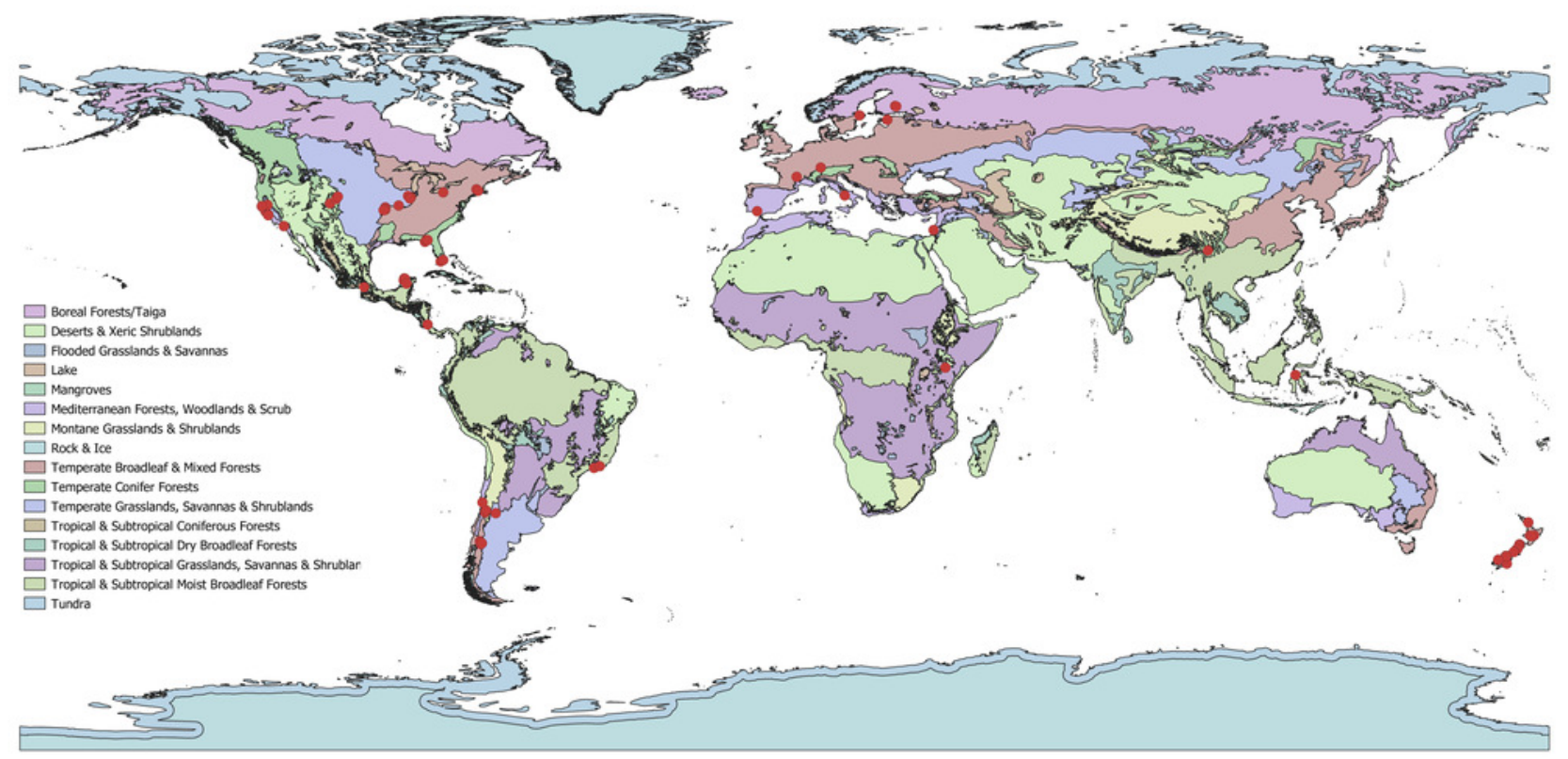




\section{Figure 4}

Network showing the interactions between herbivores, plants, and pollinators found within the 61 studies included in this review.

Links are coloured by whether herbivores had a direct, indirect, or unspecified effect (or both direct and indirect) on floral tissue within the study. Line thickness represents multiple interactions between those two species. Community refers to studies where the herbivores, plants, or pollinators consisted of whatever species were found within the natural community and not restricted. Plant species in which no herbivores or pollinators were used within the study (e.g. herbivory was artificially mimicked and pollination was measured passively through hand pollination) are not included. 


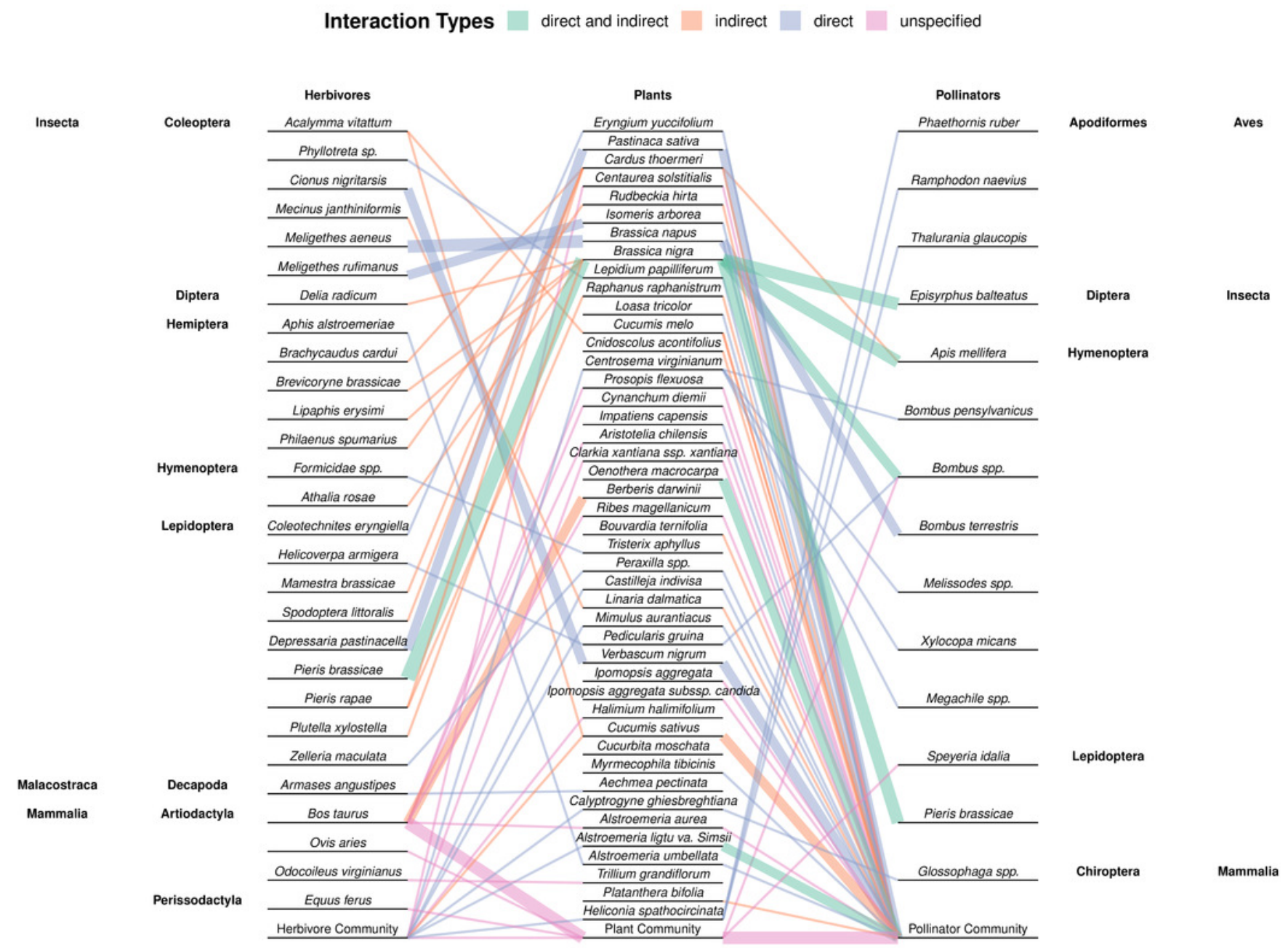




\section{Figure 5}

UpSet plot showing the number of publications $(\mathrm{N}=61)$ that examined each type of herbivory both individually and simultaneously.

The black vertical bars represent the number of publications that looked at exactly one, two or three types of herbivory. The dots directly below black bars correspond to which type(s) of herbivory are represented within that category. The coloured horizontal bars to the left of the list of herbivory types show the number of publications that included each herbivory type (regardless of whether another type of herbivory was also examined). Horizontal bars and rows are coloured according to the interaction type of each form of herbivory (i.e. direct, indirect, or unspecified). Unspecified interaction pathways are those in which one or both of direct and indirect pathways are possible, but not specified.

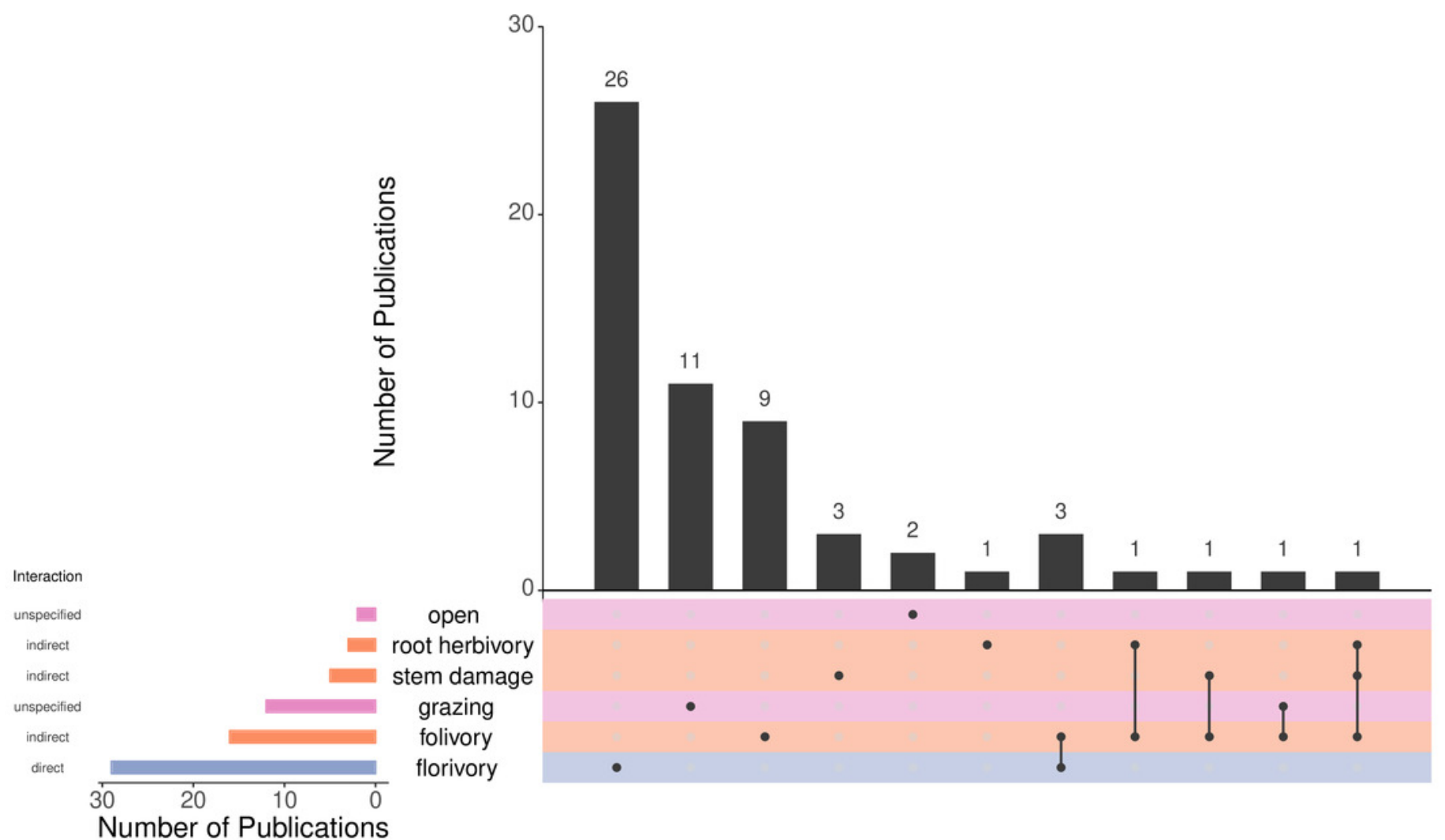




\section{Table $\mathbf{1}$ (on next page)}

Definitions and study counts of all types of herbivory as well as floral, pollinator, and plant responses included in this review.

Study counts include artificial herbivory versions for each herbivory category (e.g. both floral herbivory done by animals and human removal of petals would be included under florivory). 


\begin{tabular}{|c|c|c|c|}
\hline Term & Definition & Category & $\begin{array}{l}\text { Number } \\
\text { of } \\
\text { Studies }\end{array}$ \\
\hline Florivory & $\begin{array}{l}\text { Flower consumption, including removal of } \\
\text { flowers and inflorescences (complete } \\
\text { florivory) and partial removal of flowers } \\
\text { and petals (partial florivory) }\end{array}$ & $\begin{array}{l}\text { Floral } \\
\text { Herbivory }\end{array}$ & 29 \\
\hline Folivory & Leaf consumption & $\begin{array}{l}\text { Vegetative } \\
\text { Herbivory }\end{array}$ & 16 \\
\hline Stem damage & $\begin{array}{l}\text { Damage to the stem, including puncture } \\
\text { damage and meristem removal. }\end{array}$ & $\begin{array}{l}\text { Vegetative } \\
\text { Herbivory }\end{array}$ & 5 \\
\hline Root herbivory & Damage to or consumption of roots & $\begin{array}{l}\text { Vegetative } \\
\text { Herbivory }\end{array}$ & 3 \\
\hline Open (herbivory) & $\begin{array}{l}\text { Open to all herbivores that could consume } \\
\text { any or all plant tissues. }\end{array}$ & $\begin{array}{l}\text { Both } \\
\text { Vegetative } \\
\text { and Floral } \\
\text { Herbivory } \\
\text { with unknown } \\
\text { proportions }\end{array}$ & 3 \\
\hline Grazing & $\begin{array}{l}\text { Indiscriminate consumption of plants by } \\
\text { mammalian herbivores. }\end{array}$ & $\begin{array}{l}\text { Both } \\
\text { Vegetative } \\
\text { and Floral } \\
\text { Herbivory } \\
\text { with unknown } \\
\text { proportions }\end{array}$ & 12 \\
\hline $\begin{array}{l}\text { Flower } \\
\text { morphology/architecture } \\
\text { and size }\end{array}$ & $\begin{array}{l}\text { Refers to flower symmetry (both due to } \\
\text { faulty growth and partial floral damage), } \\
\text { inflorescence shape, and architecture, as } \\
\text { well as aspects of floral morphology } \\
\text { relating to size including diameter, surface } \\
\text { area, and corolla length }\end{array}$ & $\begin{array}{l}\text { Floral } \\
\text { Response }\end{array}$ & 16 \\
\hline Flowering phenology & $\begin{array}{l}\text { The timing of flowers, including when } \\
\text { flowers are produced and when they open }\end{array}$ & $\begin{array}{l}\text { Floral } \\
\text { Response }\end{array}$ & 5 \\
\hline Flower abundance & $\begin{array}{l}\text { The number of flowers in total. Also } \\
\text { includes the presence/absence of flowers } \\
\text { when flowers are considered individually }\end{array}$ & $\begin{array}{l}\text { Floral } \\
\text { Response }\end{array}$ & 24 \\
\hline
\end{tabular}




\begin{tabular}{|c|c|c|}
\hline sex ratio & $\begin{array}{l}\text { The relative proportion of male and female } \\
\text { flowers }\end{array}$ & $\begin{array}{l}\text { Floral } \\
\text { Response }\end{array}$ \\
\hline Floral diversity & $\begin{array}{l}\text { Number of species or other diversity metric } \\
\text { of flowering species }\end{array}$ & $\begin{array}{l}\text { Floral } \\
\text { Response }\end{array}$ \\
\hline Pollen production & $\begin{array}{l}\text { The amount of pollen produced by a flower } \\
\text { or stigma }\end{array}$ & $\begin{array}{l}\text { Floral } \\
\text { Response }\end{array}$ \\
\hline Pollen deposition & $\begin{array}{l}\text { The amount of pollen deposited by a } \\
\text { pollinator }\end{array}$ & $\begin{array}{l}\text { Pollinator } \\
\text { Effect }\end{array}$ \\
\hline Pollinator visitation & $\begin{array}{l}\text { The frequency with which a flower or plant } \\
\text { is visited by pollinators }\end{array}$ & $\begin{array}{l}\text { Pollinator } \\
\text { Effect }\end{array}$ \\
\hline Pollinator abundance & $\begin{array}{l}\text { The abundance of pollinators found in the } \\
\text { local environment }\end{array}$ & $\begin{array}{l}\text { Pollinator } \\
\text { Effect }\end{array}$ \\
\hline Pollinator diversity & $\begin{array}{l}\text { The number of pollinator species (or other } \\
\text { diversity metric) that either visit a } \\
\text { flower/plant or are found in the local } \\
\text { environment }\end{array}$ & $\begin{array}{l}\text { Pollinator } \\
\text { Effect }\end{array}$ \\
\hline Fruit set & $\begin{array}{l}\text { A number of measures that represent the } \\
\text { amount of fruit produced including number } \\
\text { of fruits, fruit size, and fruit mass }\end{array}$ & $\begin{array}{l}\text { Plant } \\
\text { Response }\end{array}$ \\
\hline Seed set & $\begin{array}{l}\text { A number of measures that represent the } \\
\text { amount of seed produced including number } \\
\text { of seeds, seed size, and seed mass. In some } \\
\text { cases, only viable seeds are considered. }\end{array}$ & $\begin{array}{l}\text { Plant } \\
\text { Response }\end{array}$ \\
\hline
\end{tabular}




\section{Table 2 (on next page)}

Distribution of studies based on herbivore-pollinator mechanism examined.

Unspecified refers to damage that may include either of vegetative and floral tissue, both or neither (damage was mimicked by the application of chemicals). 


\begin{tabular}{|c|c|c|c|c|c|}
\hline Indirect & $\mathbf{n}$ & Direct & $\mathbf{n}$ & Unspecified & $\mathbf{n}$ \\
\hline $\begin{array}{l}\text { Vegetative Damage-Floral } \\
\text { Response-Pollinator }\end{array}$ & 5 & $\begin{array}{l}\text { Floral Damage-Floral } \\
\text { Response-Pollinator }\end{array}$ & 1 & $\begin{array}{l}\text { Unspecified Damage-Floral } \\
\text { Response-Pollinator }\end{array}$ & 6 \\
\hline $\begin{array}{l}\text { Vegetative Damage-Floral } \\
\text { Response-Pollinator-Seed } \\
\text { Set }\end{array}$ & 9 & $\begin{array}{l}\text { Floral Damage-Floral } \\
\text { Response-Pollinator- } \\
\text { Seed Set }\end{array}$ & 6 & $\begin{array}{l}\text { Unspecified Damage-Floral } \\
\text { Response-Pollinator-Seed } \\
\text { Set }\end{array}$ & 2 \\
\hline $\begin{array}{l}\text { Vegetative Damage- } \\
\text { Pollinator }\end{array}$ & 3 & $\begin{array}{l}\text { Floral Damage- } \\
\text { Pollinator }\end{array}$ & 7 & $\begin{array}{l}\text { Unspecified Damage- } \\
\text { Pollinator }\end{array}$ & 0 \\
\hline $\begin{array}{l}\text { Vegetative Damage- } \\
\text { Pollinator-Seed Set }\end{array}$ & 4 & $\begin{array}{l}\text { Floral Damage- } \\
\text { Pollinator-Seed Set }\end{array}$ & 13 & $\begin{array}{l}\text { Unspecified Damage- } \\
\text { Pollinator-Seed Set }\end{array}$ & 6 \\
\hline
\end{tabular}

2 